\title{
Research on Current Situation of Educational Technology Ability for College English Teachers
}

\author{
Yu Lei, ${ }^{1, a}$,Qi Zhenguo ${ }^{2, b}$ \\ ${ }^{1}$ Foreign Language School,Shenyang Aerospace University,Shenyang, 110136,China \\ ${ }^{2}$ School of Educational Technology, Shenyang Normal University,Shenyang, 110034,China \\ ayuleicathy@126.com, ${ }^{\mathrm{b}}$ qizhenguo@126.com
}

Keywords: college English teachers; educational technology; educational informatization

\begin{abstract}
The educational technology ability for English teachers in Colleges and universities is an important part of educational informatization. Improving the educational technology ability of English teachers is the needs of the teachers' professional development and the teaching reform in education. This paper analyses the current situation of educational technology ability for English teachers in some colleges. Educational technology can change the ideas and concepts in education, promote the reform of college English teaching mode, system, contents and methods, accelerate the modernization of education and management means which are of great importance. Improving educational technology ability has far-reaching significance to the college English teachers.
\end{abstract}

\section{Introduction}

Educational informatization is the requirements and the needs of educational development. Educational modernization promoted by educational informationization is the specific measures of our country through carrying on the Scientific and Educational Strategy. "Modern educational technology is the commanding point and the breakthrough in educational reform and development. In order to realize the modernization of education and to realize the leapfrog development of education, educational informationization is a key factor. Occupied the commanding heights, you can open the door of the modern educational reform and development". The documents, such as "The CPC Central Committee, the State Council on Deepening Educational Reform, Comprehensively Promote Quality Education Decision,National Economic and Social Development of the Tenth Five Year Plan, and The Notice on the Educational Technology Training Issues for College Teachers" have pointed out the relevant requirements and importance of educational technology training for teachers in colleges and universities. The promotion of educational technology ability for college English teachers is the key part of higher education in the process of educational informatization, and the educational technology has become the core content of educational informatization.

\section{The background and the process of research}

So far, $100 \%$ of colleges and universities in China have built the campus network. $100 \%$ of them are in the construction or purchase of the network teaching platform, and are carrying out the network teaching practice. In the context of informationization, the reform of teaching mode in colleges is deepening, and college English teaching reform as one part of it, should naturally adapt to the requirement of teaching reform. The reform of college English teaching mode under the background of educational informationization has also been in full swing, and the level of English teachers' educational technology ability in the context of educational informationization will play a decisive role in its success[1].

Here, the definition of college English teaching refers to the public English teaching in colleges. In order to fully understand the current situation of college English teachers' educational technology ability and to know about the English teaching reform in colleges under the background of informationization, the research group is carrying on an in-depth study by using the methods of 
survey, interview, observation and so on. 200 English teachers in certain colleges and universities are studied and interviewed, whose title and degree are varied from professors to lecturers, and from Dr to Bachelor, who work as college English teachers for more than 3 years. Most of the teachers can accept the reform of the new teaching model, not systematically understand the educational informationization and know little about the educational technology, but all of them express their interest. Through the investigation and study, the current situation of college English teachers' educational technology ability can be understood, hence, the relevant strategies to enhance the ability of educational technology can be made up,which some experimental schools can implement and evaluate.

\section{The investigation on the current situation of educational technology ability for college English teachers}

The research group has investigated the current situation of teachers' educational technology ability, from the basic awareness of educational technology and the basic skills in educational technology to the application of educational technology. The results show that the knowledge of educational technology among the college English teachers has greatly improved than before, and almost every teacher hears about the educational technology. Most of the teachers expressed their interest in educational technology and want to learn it. The teachers who know about the basic concepts of educational technology are less, only about $10 \%$ of whom can express clearly the concepts and connotation of educational technology, and the vast majority of whom think that educational technology is the application of computer teaching. About $50 \%$ of the teachers can understand the basic theory of educational technology, about $40 \%$ of whom think that they have mastered the basic skills of educational technology, and about $80 \%$ of whom have applied the educational technology to the English teaching. The results of Chen Yunhong's survey on the educational technology ability of teachers in different disciplines in 21 universities show that 82.3\% of the teachers are very interested or interested in the educational technology, $17.7 \%$ of whom know little about the educational technology and think that the educational technology is common or they are not interested in it. There are about $60 \%$ college teachers focusing on the design of teaching process and teaching environment in the process of teaching, $41 \%$ of whom often use online resources, $50.8 \%$ of whom sometimes use them, and rarely or never used accounted for only $8.2 \%$. $73.6 \%$ of the local college and university teachers never participated in producing the teaching courseware[2].

\section{A. The Awareness of Educational Technology}

From the results of investigation, the majority of English teachers have the awareness of educational technology, but most teachers feel that the requirement of the educational informatization is too high, and they have acknowledged the importance of educational technology but not understand or accept it psychologically. Taken together, the English teachers hold the positive attitudes to the educational technology, but due to lack of the relevant knowledge of educational technology, it limits their application of educational technology in the English teaching. From the results of investigation, only a part of teachers, who are from Normal colleges, have learned the knowledge of educational technology in their pre-service. ( see Table 1 )

TABle I. The InVESTIGATION OF EduCATIONAL TECHNOLOGY FOR COLlEGE ENGLiSH TEACHERS

\begin{tabular}{|c|c|c|c|c|c|}
\hline \multirow{3}{*}{\begin{tabular}{l}
\multicolumn{3}{c}{ Results of Investigation } \\
Do you know about \\
educational technology?
\end{tabular}} & \multicolumn{3}{|c|}{ Content and Options } & \multirow[b]{2}{*}{ indifferent } & \multirow[b]{2}{*}{ no } \\
\hline & very well & yes & a little & & \\
\hline & $5 \%$ & $15 \%$ & $44 \%$ & $24 \%$ & $12 \%$ \\
\hline \multirow{2}{*}{$\begin{array}{l}\text { Do you think educational } \\
\text { technology can promote the } \\
\text { English teaching? }\end{array}$} & greatly & yes & unclear & little & no \\
\hline & $32 \%$ & $47 \%$ & $6 \%$ & $7 \%$ & $8 \%$ \\
\hline \multirow{2}{*}{$\begin{array}{l}\text { Have you ever applied } \\
\text { educational technology to } \\
\text { English teaching? }\end{array}$} & often & occasionally & never & & \\
\hline & $27 \%$ & $52 \%$ & $21 \%$ & & \\
\hline \multirow{2}{*}{$\begin{array}{l}\text { Have you studied Modern } \\
\text { Educational Technology? }\end{array}$} & yes & no & & & \\
\hline & $34 \%$ & $66 \%$ & & & \\
\hline
\end{tabular}




\begin{tabular}{|c|c|c|c|c|c|}
\hline \multirow{2}{*}{$\begin{array}{l}\text { Does your unit attach } \\
\text { importance to teachers' } \\
\text { educational technology ability? }\end{array}$} & greatly & yes & unknown & little & no \\
\hline & $12 \%$ & $35 \%$ & $31 \%$ & $15 \%$ & $7 \%$ \\
\hline \multirow{2}{*}{$\begin{array}{l}\text { Do you think educational } \\
\text { technology ability is necessary } \\
\text { for English teachers? }\end{array}$} & greatly & yes & unclear & little & no \\
\hline & $35 \%$ & $52 \%$ & $4 \%$ & $6 \%$ & $3 \%$ \\
\hline \multirow{2}{*}{$\begin{array}{l}\text { What about educational } \\
\text { technology environment } \\
\text { ( hardware ) in your school? }\end{array}$} & very good & good & unclear & not good & very poor \\
\hline & $23 \%$ & $36 \%$ & $21 \%$ & $13 \%$ & $7 \%$ \\
\hline
\end{tabular}

\section{B. The Application of Educational Technology}

The data shows that English teachers need to be strengthened in the two aspects-the skills of basic knowledge in educational technology and the skills of teaching practice. Teaching design, information technology, curriculum integration, network course, learning website, the production of teaching courseware and other aspects are closely related to the English teaching, and the teachers' mastery of these techniques is not very good, so they need to learn and practice. ( see Table 2)

TABle II. The MASTERY OF EdUCATIONAL TECHNOLOgY FOR COLLEgE ENGLiSh TEACHERS

\begin{tabular}{|c|c|c|c|c|c|c|}
\hline \multirow{2}{*}{\multicolumn{2}{|c|}{ Content of Investigation }} & \multicolumn{5}{|c|}{ Options and Results } \\
\hline & & good & common & unclear & poor & very poor \\
\hline \multirow[b]{2}{*}{ Basic knowledge } & Theory of educational technology & 0 & $14 \%$ & $47 \%$ & $23 \%$ & $16 \%$ \\
\hline & Basic knowledge of Computer & $8 \%$ & $35 \%$ & $24 \%$ & $21 \%$ & $12 \%$ \\
\hline \multirow[t]{2}{*}{ and skills of } & $\begin{array}{lll}\begin{array}{l}\text { Network and } \\
\text { technology }\end{array} & \text { communicative } \\
\end{array}$ & $1 \%$ & $13 \%$ & $23 \%$ & $42 \%$ & $21 \%$ \\
\hline & Courseware design and making & $15 \%$ & $34 \%$ & $27 \%$ & $21 \%$ & $3 \%$ \\
\hline educational & $\begin{array}{l}\text { Website construction and webpage } \\
\text { design }\end{array}$ & $2 \%$ & $12 \%$ & $11 \%$ & $43 \%$ & $32 \%$ \\
\hline \multirow[t]{3}{*}{ technology } & $\begin{array}{l}\text { Design and production of } \\
\text { presentation }\end{array}$ & $41 \%$ & $30 \%$ & $7 \%$ & $15 \%$ & $7 \%$ \\
\hline & Image, video processing & $7 \%$ & $22 \%$ & $17 \%$ & $32 \%$ & $22 \%$ \\
\hline & Audio processing technology & $9 \%$ & $25 \%$ & $20 \%$ & $27 \%$ & $19 \%$ \\
\hline \multirow{4}{*}{ Skills of teaching } & Design of teaching system & $23 \%$ & $31 \%$ & $14 \%$ & $20 \%$ & $12 \%$ \\
\hline & $\begin{array}{l}\text { Design and analysis of teaching and } \\
\text { learning environment }\end{array}$ & $21 \%$ & $26 \%$ & $18 \%$ & $21 \%$ & $14 \%$ \\
\hline & $\begin{array}{l}\text { Integration of information } \\
\text { technology with curriculum }\end{array}$ & $15 \%$ & $32 \%$ & $17 \%$ & $31 \%$ & $5 \%$ \\
\hline & Network curriculum design & $11 \%$ & $31 \%$ & $24 \%$ & $27 \%$ & $7 \%$ \\
\hline
\end{tabular}

\section{The Demand of Educational Technology for English Teachers}

College English teachers have showed positive attitudes towards the demand of educational technology, especially they are more interested in the demand of courseware design and making, integration of information technology with curriculum, network course and network teaching. ( see Figure 1 )

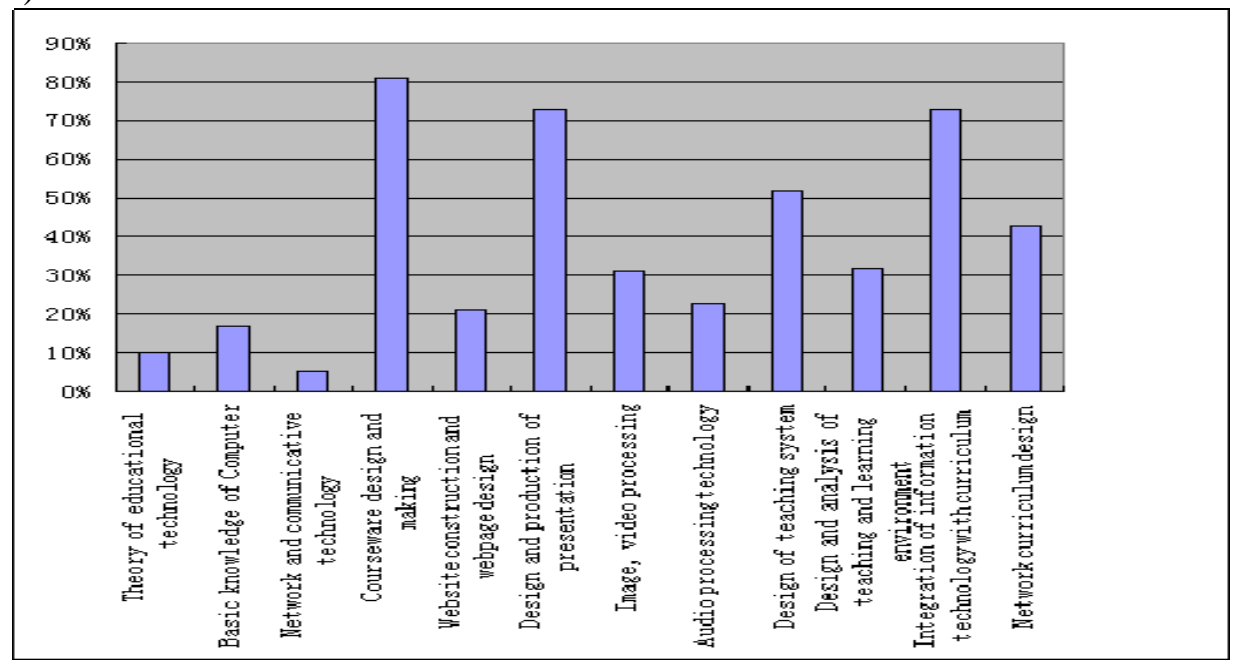

Fig.1.The demand of educational technology for college English teachers

D. The Problems Existed

The teaching concepts can not be timely changed: in the face of the English teaching reform 
under the background of informatization, some teachers feel uncomfortable and think that the new teaching mode will affect their English teaching. English teaching under the background of informatization are of great changes in the teaching means and methods[3]. Interactive teaching has been flexible and teaching resources have become electronic, which bring a revolution to the college English teaching.

The fear of technology: nearly all the college English teachers have the background of liberal arts, so they have the fear of technology. The complex network teaching system and electronic content make them nervous and fearful. The management department of teaching platform ( office of academic affairs or the modern educational technology center ) often makes irregular system update and data processing, which make some teachers worry about the missing of data or the teaching contents stored in the teaching platform system. Teachers are concerned about the reliability of the network teaching platform, and frequently updated operating system and application software also give them some pressure.

Lack of policy and humanistic environment: although some schools have perfect teaching environment and hardware facilities, and the environment of technology can meet the need of English teaching under the background of informatization, but the schools ignore the training for the teachers' educational technology ability, or have no relevant requirements and policy support for the college English teaching reform, or lack of policy guidance for English teachers in English teaching reform under the background of informatization, or have no clear requirements for English teachers' educational technology ability, and chill the enthusiasm of teachers in English teaching reform[4].

\section{Summary and Reflection}

The ascension of educational technology ability for college English teachers is a long-term task, and the process of it is a systematic engineering. Improving the education technology ability for college English teachers does not only refer to the technical aspects of the process of ascension, but also refer to the reshaping process of the educating and teaching concepts. Policy support involves taking full consideration into the subjective thinking and motivation of teachers. In addition, the training budget for college English teachers is very tight, which is an unavoidable problem to solve in the process of improving the educational technology ability for college English teachers, but they need to be provided with the necessary funding support and training. Improving the educational technology ability for college English teachers requires the country, the educational administrative departments, schools and teachers' working together to complete.

\section{Acknowledgment}

I would like to express my deep appreciation and gratitude to those special people who have supported and assisted me in completing my research. These special people allowed me to share my vision with them and encouraged its fruition through their suggestions, guidance, participation, and encouragement.

\section{References}

[1] Chen Yunhong, Xie Baizhi, and Su Bo, "Analysis and Research on The Current Situation of College Teachers' Educational Technology Ability,” Chinese Medical Educational Technology , pp. 304-306, August 2008.

[2] Yu Lei, and Qi Zhenguo, "Digital Learning Brings Challenges for Chinese College English Teachers,” Distance Education in China, pp.73-76, August 2011.

[3] Zhong Zhixian, "Information Teaching Mode,” Beijing Normal University Press, pp.74-75, 2006.

[4] “Education Training Program in Higher Grade School,” Http://www.metc.pku.edu.cn 